\title{
SF3B1 mutant myelodysplastic syndrome: recent advances
}

Andrea Pellagatti and Jacqueline Boultwood

Blood Cancer UK Molecular Haematology Unit, Nuffield Division of Clinical Laboratory Sciences, Radcliffe Department of Medicine, University of Oxford, and Oxford BRC Haematology Theme, Oxford, UK

\section{Corresponding authors:}

Andrea Pellagatti and Jacqueline Boultwood

Nuffield Division of Clinical Laboratory Sciences

Radcliffe Department of Medicine, University of Oxford

John Radcliffe Hospital

Oxford OX3 9DU

United Kingdom

Telephone: +441865220480

Email: andrea.pellagatti@ndcls.ox.ac.uk and jacqueline.boultwood@ndcls.ox.ac.uk 


\begin{abstract}
The myelodysplastic syndromes (MDS) are common myeloid malignancies. Mutations in genes encoding different components of the spliceosome occur in more than half of all MDS patients. $S F 3 B 1$ is the most frequently mutated splicing factor gene in MDS, and there is a strong association between $S F 3 B 1$ mutations and the presence of ring sideroblasts in the bone marrow of MDS patients. It has been recently proposed that $S F 3 B 1$ mutant MDS should be recognized as a distinct nosologic entity. Splicing factor mutations cause aberrant pre-mRNA splicing of many target genes, some of which have been shown to impact on hematopoiesis in functional studies. Emerging data show that some of the downstream effects of different mutated splicing factors converge on common cellular processes, such as hyperactivation of NF- $\kappa \mathrm{B}$ signaling and increased R-loops. The aberrantly spliced target genes and the dysregulated pathways and cellular processes associated with splicing factor mutations provided the rationale for new potential therapeutic approaches to target MDS cells with mutations of $S F 3 B 1$ and other splicing factors.
\end{abstract}

Keywords: Myelodysplastic syndromes; splicing factor gene mutations; SF3B1 mutation; RNA splicing; NF- $\mathrm{BB}$ signaling; R-loops 


\section{Introduction}

The myelodysplastic syndromes (MDS) are common myeloid malignancies (Steensma, 2015; Ogawa, 2019), with patients suffering from anemia and other cytopenias leading to a higher risk of infections. MDS patients show increasing blasts in their bone marrow as the disease progresses, and $\sim 30-40 \%$ develop a secondary acute myeloid leukemia (sAML). The prognosis of patients with high-risk MDS is poor, with a median survival of less than two years (Greenberg et al., 2012). Some effective treatments exist for MDS (Steensma, 2015; Chamseddine et al., 2016), and allogeneic hematopoietic stem cell (HSC) transplantation is the only curative treatment, but it is only suitable for a small proportion of cases (de Witte et al., 2017).

The complex mutational landscape of MDS has been illuminated using next-generation sequencing (Papaemmanuil et al., 2011; Yoshida et al., 2011; Papaemmanuil et al., 2013; Haferlach et al., 2014; Pellagatti and Boultwood, 2015; Pellagatti et al., 2016). The large majority of MDS patients harbor one or more gene mutations (Papaemmanuil et al., 2013; Haferlach et al., 2014), and the most common mutations affect genes involved in pre-mRNA splicing (e.g. SF3B1, SRSF2, U2AF1 and ZRSR2) (Papaemmanuil et al., 2011; Yoshida et al., 2011; Papaemmanuil et al., 2013; Haferlach et al., 2014). SF3B1 is the most frequently mutated splicing factor gene in MDS (frequency 20-28\%), and SF3B1 mutations are strongly associated with the presence of ring sideroblasts (i.e. erythroblasts with iron-loaded mitochondria) in the bone marrow (Malcovati et al., 2011). It is interesting to note that $S F 3 B 1$ mutations are found in some individuals with clonal hematopoiesis of indeterminate potential (Steensma et al., 2015). SRSF2 mutations occur in approximately $15 \%$ of MDS patients, with a higher frequency in patients with chronic myelomonocytic leukemia (CMML) (40-50\% of cases) (Meggendorfer et al., 2012; Papaemmanuil et al., 2013; Patnaik et al., 2013; Haferlach et al., 2014; Patel et al., 2017), and U2AF1 mutations occur in 7-11\% in MDS patients (Yoshida et al., 2011; Thol et al., 2012; Papaemmanuil et al., 2013; Haferlach et al., 2014; Ogawa, 2019).

We have previously reviewed the role played by the common splicing factor gene mutations in MDS pathogenesis (Pellagatti and Boultwood, 2017; Armstrong et al., 2018; Pellagatti and Boultwood, 2020b). Here, we will focus on the latest studies and most recent advances 
concerning the impact of mutations of $S F 3 B 1$, the most commonly mutated splicing factor gene in MDS, on MDS classification, patient survival, disease pathophysiology and treatment.

\section{SF3B1 mutations: MDS disease classification and patient survival}

Previous studies have shown that splicing factor mutations define clinical phenotypes in MDS to some degree (Papaemmanuil et al., 2011; Yoshida et al., 2011), and have different impacts on patient survival (Joshi et al., 2017; Pellagatti and Boultwood, 2017; Saez et al., 2017; Ogawa, 2019).

Within MDS, the presence of a $S F 3 B 1$ mutation identifies a condition that is characterized by the presence of ring sideroblasts (RS) in the bone marrow, ineffective erythropoiesis, and an indolent clinical course. The international working group for the prognosis of MDS has recently proposed that $S F 3 B 1$ mutant MDS should be recognised as a distinct disease subtype (Malcovati et al., 2020). The proposed diagnostic criteria for MDS with mutated SF3B1 are (1) cytopenia, (2) somatic SF3B1 mutation, (3) erythroid or multilineage morphologic dysplasia (irrespective of RS), (4) bone marrow blasts $<5 \%$ and peripheral blood blasts $<1 \%$, and (5) absence of genetic lesions with significant negative prognostic value (Malcovati et al., 2020).

Patients with idiopathic cytopenia of undetermined significance not fulfilling diagnostic criteria for MDS are labelled as clonal cytopenia of undetermined significance (CCUS). Interestingly, in patients with CCUS, SF3B1 mutations are almost invariably associated with the subsequent development of overt MDS with RS, suggesting that SF3B1 mutation might provide presumptive evidence of MDS even if definitive morphological features are absent (Malcovati et al., 2020).

The diagnosis of SF3B1 mutant MDS has important clinical implications in terms of risk stratification, since these patients have a relatively good prognosis, and also for therapeutic decision-making, as treatment of anemia with the drug luspatercept can be particularly effective in patients with $S F 3 B 1$ mutant MDS-RS (Fenaux et al., 2020).

Splicing factor mutations have different impacts on patient survival: SF3B1 mutations confer 
a favorable prognosis in MDS (Malcovati et al., 2011; Papaemmanuil et al., 2011; Malcovati et al., 2015; Ogawa, 2019), whereas SRSF2 or U2AF1 mutations are associated with shorter patient survival (Graubert et al., 2011; Bejar et al., 2012; Makishima et al., 2012; Thol et al., 2012; Wu et al., 2012; Patnaik et al., 2013; Walter et al., 2013; Wu et al., 2013; Wu et al., 2016; Ogawa, 2019). Several studies have shown that MDS patients with SF3B1 mutations rarely progress to sAML (Malcovati et al., 2015; Pellagatti et al., 2016; Pellagatti and Boultwood, 2017; Armstrong et al., 2018), while patients with SRSF2 or U2AF1 mutations typically have an increased risk of AML transformation (Graubert et al., 2011; Bejar et al., 2012; Makishima et al., 2012; Thol et al., 2012; Wu et al., 2012; Patnaik et al., 2013; Walter et al., 2013; Wu et al., 2013; Wu et al., 2016; Ogawa, 2019).

These observations have been confirmed in a recent study in which a meta-analysis of 19 studies has been performed to evaluate the effects of splicing factor mutations on the overall survival and leukemia-free survival of MDS patients (Wang et al., 2019). In agreement with the previous reports described above, this study concluded that SF3B1 mutations are associated with better survival and lower risk of progression to AML, whereas SRSF2 and $U 2 A F 1$ mutations are associated with shorter survival and increased risk of progression to AML (Wang et al., 2019). However, there was some variability in the overall survival of SF3B1 mutant MDS patients in different studies (Wang et al., 2019), and a potential contributing factor might be the location of the mutation within the open reading frame of the SF3B1 gene. Indeed, a recent study by Dalton et al. showed that among different SF3B1 mutations the K666N hotspot is distinctly associated with high-risk MDS and AML, as this mutation occurs more frequently in MDS cases with excess blasts and in AML (Dalton et al., 2020). Furthermore, this study showed that MDS patients with the SF3B1 K666N mutation have higher IPSS-R scores and that this mutation is associated with a shorter overall survival (Dalton et al., 2020). These results suggest that MDS patients with the SF3B1 K666N mutation may require more aggressive treatment than patients with other SF3B1 mutations.

\section{SF3B1 mutations: characteristics, co-occurring mutations and models of co-operating mutations}

Most splicing factor mutations in MDS are heterozygous missense mutations (Yoshida et al., 
2011; Damm et al., 2012; Papaemmanuil et al., 2013; Haferlach et al., 2014). SF3B1, SRSF2 and $U 2 A F 1$ mutations are considered to be change-of-function/neomorphic or gain-offunction mutations, while ZRSR2 mutations are loss-of-function (Papaemmanuil et al., 2011; Yoshida et al., 2011; Yip et al., 2016).

It is recognized that splicing factor mutations are mutually exclusive (Yoshida et al., 2011; Papaemmanuil et al., 2013). However, rare myeloid malignancy patients with two co-occurring splicing factor mutations have been reported (Papaemmanuil et al., 2013; Haferlach et al., 2014; Shiozawa et al., 2018; Bondu et al., 2019). In a recent study, Taylor et al investigated the frequency and characteristics of such patients (Taylor et al., 2020). The analysis of genomic DNA sequencing data from more than 4,000 myeloid malignancy patients, including 58 cases with two co-occurring splicing factor mutations, showed that the mutations co-existed within the same cell in two thirds of cases (Taylor et al., 2020). Importantly, it was shown that the most frequent splicing factor mutations, SF3B1 K700 and SRSF2 P95/P96, were significantly less common in double mutants than in single mutants, indicating selection against cells harboring this specific mutation combination (Figure 1). In contrast, selection was observed for less common mutations of SF3B1 (E622, H662, K666) and SRSF2 (rare amino acid substitutions at P95), and for combined U2AF1 S34/Q157 mutations (Figure 1). Single-cell DNA sequencing of bone marrow cells from patients with two splicing factor mutations elegantly confirmed the mutual exclusivity of SF3B1 K700E and SRSF2 P95H mutations, and the co-occurrence of the less frequent splicing factor mutant alleles. In one case with U2AF1 S34 and Q157 mutations, these mutations were shown to co-occur in cis with preservation of one wildtype allele. This study concluded that co-occurrence or exclusivity of splicing factor mutations is allele-specific rather than gene-specific (Taylor et al., 2020).

Several large-scale next-generation sequencing studies have reported that splicing factor mutations are positively and negatively associated with other specific mutations (Papaemmanuil et al., 2013; Haferlach et al., 2014; Makishima et al., 2017). It has been shown that SF3B1 mutations are mutually exclusive with mutations associated with disease progression or transformation in MDS (Makishima et al., 2017), and that SF3B1 mutations are rare in MDS cases that show disease progression to AML (Pellagatti et al., 2016; Makishima et al., 2017). This may explain, at least in part, the relatively good prognosis of MDS patients with $S F 3 B 1$ mutations.

Mutations of the tumor-suppressor gene TP53 in MDS are associated with transformation 
to AML (Bejar et al., 2011; Haase et al., 2019), and TP53-mutant MDS patients can harbor monoallelic mutations of this gene or multiple hits (multi-hit) consistent with biallelic targeting (Bernard et al., 2020). The TP53 multi-hit state in MDS was recently shown to be an independent predictor for the risk of death and AML transformation, whereas MDS patients with monoallelic TP53 mutations did not differ from TP53 wild-type patients in outcomes and response to therapy (Bernard et al., 2020). Consistent with the association of SF3B1 mutations with a favorable prognosis, MDS patients with monoallelic TP53 mutations were significantly enriched for SF3B1 mutations (Bernard et al., 2020).

Splicing factor mutations are typically founder mutations (Mian et al., 2013; Papaemmanuil et al., 2013; Haferlach et al., 2014; Mian et al., 2015). In a recent study, Nagata et al investigated the clonal architecture of MDS and showed that splicing factor mutations, including $S F 3 B 1$ mutations, were more likely to be dominant (i.e. belonging to the largest clone) (Nagata et al., 2019). Dominant SF3B1 mutations were significantly associated with secondary mutations of $J A K 2$ and DNMT3A (Nagata et al., 2019). Overall, the results of this study suggest that after an initial mutation, subsequent hits are not random, with certain dominant/secondary mutation combinations occurring more commonly (Nagata et al., 2019).

How splicing factor mutations cooperate with other mutations to give the MDS phenotype is being actively investigated (Obeng et al., 2016; Chang et al., 2018; Fei et al., 2018; Hsu et al., 2019; Yoshimi et al., 2019).

The introduction of a Tet 2 deletion in a Sf3b1-K700E mouse model exacerbated the macrocytic anemia and impaired terminal erythroid maturation, accelerated long-term HSC expansion, and rescued the competitive repopulation disadvantage conferred by the $S f 3 b 1$ mutation alone (Obeng et al., 2016). The presence of both genomic lesions thus mirror the MDS phenotype more accurately.

MDS patient-derived induced pluripotent stem cells (iPSCs) and CRISPR/Cas9 gene editing have been used to determine the effects of sequential gene mutations on the disease phenotype (Hsu et al., 2019). SF3B1 and EZH2 mutations were shown to co-operate in perturbing mitochondrial function, leading to the accumulation of damaged mitochondria, and resulting in ineffective erythropoiesis (Hsu et al., 2019).

In a recent study concerning another commonly mutated splicing factor gene, SRSF2, Yoshimi et al. investigated how mutations affecting splicing and epigenetic regulation may promote leukemogenesis (Yoshimi et al., 2019). SRSF2 mutations were found to co-occur 
frequently with mutations of the epigenetic regulator $I D H 2$ in patients with AML. $\operatorname{Srsf} 2^{\mathrm{P} 95 \mathrm{H}} / \mathrm{Idh} 2^{\mathrm{R} 140 \mathrm{Q}}$ double knock-in mice developed a lethal MDS with proliferative features and significantly shorter survival. The analysis of transcriptome data from AML patient cohorts revealed more profound splicing changes in SRSF2/IDH2 double-mutant patients than in patients with either mutation (Yoshimi et al., 2019). INTS3, encoding a component of the Integrator complex that participates in small nuclear RNA processing (Wu et al., 2017), was identified as a key aberrantly spliced target gene in SRSF2/IDH2 double-mutant AML cells. Aberrant INTS3 splicing resulted in nonsense-mediated decay (NMD) of its transcript and reduced protein expression. In functional studies, restoration of INTS3 expression in IDH2/SRSF 2 double-mutant HL-60 cells resulted in release from a differentiation block. Xenografts of IDH2/SRSF2 mutant HL-60 cells showed that forced expression of INTS3 induced myeloid differentiation and slowed leukemia progression (Yoshimi et al., 2019). This study concluded that SRSF2 and IDH2 mutations can promote leukemogenesis through coordinated effects on the epigenome and pre-mRNA splicing (Yoshimi et al., 2019).

These reports demonstrate the utility of various in vitro and in vivo models of MDS in the study of this disorder, illuminating how splicing factor mutations and other mutations cooperate and contribute to disease pathophysiology.

\section{SF3B1 mutations: aberrant pre-mRNA splicing and target genes}

Alternative pre-mRNA splicing, leading to the production of multiple mRNA isoforms, occurs in more than $90 \%$ of human protein-coding genes and represents a major source of protein diversity (Wahl et al., 2009; Nilsen and Graveley, 2010; Matera and Wang, 2014; Pellagatti and Boultwood, 2017; Saez et al., 2017). The splicing factors most frequently mutated in MDS are involved in the $3^{\prime}$ splice site recognition process during pre-mRNA splicing (Yoshida et al., 2011). It is recognized that splicing factor mutations cause aberrant 3' splice site recognition (Yoshida et al., 2011; Pellagatti and Boultwood, 2017), leading to the generation of aberrantly spliced mRNAs in the bone marrow cells of myeloid malignancy patients and in mouse models that express these mutations (Colla et al., 2015; Dolatshad et al., 2015; Kim et al., 2015; Madan et al., 2015; Shirai et al., 2015; Dolatshad et al., 2016; Obeng et al., 2016; Joshi et al., 2017; Mupo et al., 2017; Pellagatti and Boultwood, 2017; 
Saez et al., 2017; Shirai et al., 2017; Yip et al., 2017; Fei et al., 2018; Kon et al., 2018; Pellagatti et al., 2018; Shiozawa et al., 2018).

The altered pre-mRNA binding specificity, some aberrantly spliced target genes identified in MDS and the mouse models of the most common splicing factor mutations have all been described in previous reviews (Inoue et al., 2016; Pellagatti and Boultwood, 2017; Saez et al., 2017; Armstrong et al., 2018; Ogawa, 2019).

Two recent studies have determined the aberrantly spliced genes in the bone marrow $\mathrm{CD}^{+} 4^{+}$cells of large cohorts of splicing factor mutant MDS patients using RNA sequencing (Pellagatti et al., 2018; Shiozawa et al., 2018). Pellagatti et al. identified dysregulated pathways and cellular processes associated with the presence of SF3B1, SRSF2 or U2AF1 mutations, as well as aberrantly splicing events associated with clinical variables, and isoforms that independently predicted survival in MDS in multivariate models (Pellagatti et al., 2018).

A number of observations concerning the analysis of SF3B1 mutant MDS cases were made in these two studies (Pellagatti et al., 2018; Shiozawa et al., 2018).

SF3B1 mutations were mainly associated with intron retention events and the use of cryptic 3' splice sites (Pellagatti et al., 2018; Shiozawa et al., 2018). The use of an alternative 3' splice site (A3SS) may cause a frameshift leading to the generation of a premature stop codon and subsequent gene downregulation via nonsense-mediated decay (NMD) of the transcript. Depending on their location within the gene, retained introns may lead to NMD or increase mRNA stability (Jacob and Smith, 2017).

A reduced level of intron retention in some pre-mRNA transcripts was observed in $S F 3 B 1$ mutant samples in both studies (Pellagatti et al., 2018; Shiozawa et al., 2018). Pellagatti et al suggested that reduced intron retention might result from the ability of the mutant SF3B1 to use an upstream 3' splice site, since a concomitant usage of an alternative 3' splice site was observed for several of the retained intron events identified (Pellagatti et al., 2018). Shiozawa et al. reported that reduced intron retention was more pronounced in the cytoplasm than in the nucleus of SF3B1 mutant cells, indicating that nuclear export of intron-retaining transcripts may be impaired in these cells (Shiozawa et al., 2018). In a recent study, Hershberger et al also showed reduced levels of retained introns in the bone marrow cells of patients with myeloid neoplasms, with a more pronounced reduction in patients with splicing factor mutations (Hershberger et al., 2020). 
The impact on hematopoiesis of some aberrantly spliced target genes associated with SF3B1 mutations has been investigated.

In the study by Pellagatti et al. the mitosis regulators SEPT2, one of the aberrantly spliced target genes of mutant SF3B1, was knocked down in $\mathrm{CD}_{3} 4^{+}$cells from healthy controls; reduced expression of this gene resulted in impaired erythroid cell growth and differentiation (Pellagatti et al., 2018).

We and others have identified aberrant splicing of genes involved in iron homeostasis in SF3B1 mutant MDS (Dolatshad et al., 2016; Pellagatti et al., 2018; Shiozawa et al., 2018; Bondu et al., 2019). It was over a decade ago that we first reported a strong association between decreasing expression levels of the iron transporter $A B C B 7$ and an increasing percentage of RS in the bone marrow cells of MDS patients (Boultwood et al., 2008). A number of studies (Nikpour et al., 2013; Dolatshad et al., 2016; Shiozawa et al., 2018) collectively support a model in which down-regulation of $A B C B 7$, resulting from aberrant splicing due to $S F 3 B 1$ mutations, underlies the increased mitochondrial iron accumulation observed in MDS patients with RS. It has been recently shown that $A B C B 7$ expression was reduced in SF3B1 mutant iPSCs from individual MDS-RS patients (Clough et al., 2020). Notably, overexpression of $A B C B 7$ partially rescued the RS phenotype in erythroid cells differentiated from the $S F 3 B 1$ mutant iPSCs, further supporting the important role of ABCB7 in the formation of RS (Clough et al., 2020). Interestingly, the inherited disorder X-linked sideroblastic anemia with ataxia is caused by partial loss-of-function mutations of $A B C B 7$ (Allikmets et al., 1999; Bekri et al., 2000), and the $A B C B 7$ down-regulation observed in SF3B1 mutant MDS provides an important link between inherited and acquired forms of sideroblastic anemia.

In a recent study, an aberrantly spliced transcript of the gene encoding the erythroid hormone erythroferrone (ERFE) was identified in the bone marrow mononuclear cells of MDS patients with SF3B1 mutations (Bondu et al., 2019). Usage of an alternative 3' splice site leads to the addition of 12 nucleotides to the open reading frame of the ERFE transcript that generates a variant ERFE protein containing a four amino acid (valine-prolinephenylalanine-glutamine - VPFQ) insertion immediately upstream of the collagen domain. The variant ERFE $\mathrm{VPF}$ maintained the capacity to suppress transcription of the iron homeostasis regulator hepcidin. ERFE concentration was found to be higher in the plasma of SF3B1 mutant MDS patients compared to SF3B1 wild-type cases, suggesting that hepcidin 
suppression by the variant ERFE protein may be responsible for the increased iron loading in SF3B1 mutant MDS patients. ERFE might represent a new target for the prevention of ironmediated toxicity (Bondu et al., 2019).

Aberrant splicing of the target gene $B R D$ 9, encoding a core component of the non-canonical BAF chromatin-remodeling complex, has been recently reported in cancer and leukemia cell lines with $S F 3 B 1$ mutation, as well as in $S F 3 B 1$ mutant MDS, chronic lymphocytic leukemia (CLL) and uveal melanoma patient samples (Inoue et al., 2019). Mutant SF3B1 recognizes an aberrant intronic branchpoint, resulting in the inclusion of a poison exon that interrupts the open reading frame of $B R D 9$. The inclusion of this poison exon leads to NMD of the $B R D 9$ transcript and reduced protein levels. Although the impact of aberrant BRD9 splicing on hematopoiesis was not evaluated, depletion of BRD9 was shown to promote melanomagenesis. Interestingly, correction of $B R D 9$ mis-splicing in SF3B1 mutant melanoma cells using antisense oligonucleotides suppressed cell growth in vitro and tumor growth in vivo. The observed tumor-suppressive effects of $B R D 9$ mis-splicing correction suggests that oligonucleotide-based therapy targeting $B R D 9$ may represent a potential new approach for treating SF3B1 mutant malignancies (Inoue et al., 2019).

\section{SF3B1 mutations and hyperactivation of NF-kB signaling}

Two studies have recently demonstrated that mutations in different splicing factors $(S F 3 B 1$, $S R S F 2$ and $U 2 A F 1$ ) enhance NF- $\mathrm{kB}$ signaling via aberrant splicing of different target genes (Lee et al., 2018; Smith et al., 2019). NF- $\mathrm{BB}$ is a transcription factor involved in the control of inflammation and innate and adaptive immunity, as well as cell proliferation, differentiation and survival (Oeckinghaus and Ghosh, 2009).

Lee et al. showed that mutant SF3B1 promotes aberrant splicing of the MAP3K7 gene, leading to NMD of the affected transcript in human and mouse hematopoietic cells (Lee et al., 2018). Reduced MAP3K7 protein levels were observed in $S F 3 B 1$ mutant human leukemia cell lines and in SF3B1 mutant MDS and CLL patient hematopoietic cells. Functional data were consistent with $\mathrm{NF}-\kappa \mathrm{B}$ signaling hyperactivation being mediated through aberrant splicing of $M A P 3 K 7$ associated with the presence of $S F 3 B 1$ mutations. In the same study, the authors showed that SRSF2 mutations were associated with aberrantly splicing of CASP8, a 
key activator of NF- $\mathrm{BB}$ (Chaudhary et al., 2000; Hu et al., 2000; Shikama et al., 2003), with promotion of NF-אB signaling (Lee et al., 2018). Interestingly, SF3B1 mutations have been shown to cause aberrant splicing of $M A P 3 K 7$, leading to reduced transcript and protein levels and resulting in enhanced NF- $\mathrm{KB}$ signaling, also in mammary epithelial and breast cancer cell lines (Liu et al., 2020).

More recently, Smith et al. showed that IRAK4, a serine/threonine kinase that mediates signaling downstream of toll-like receptors, is aberrantly spliced in MDS patients with U2AF1 mutations (Pellagatti et al., 2018; Smith et al., 2019). This aberrantly splicing event results in increased production of the full-length isoform that retains exon 4 (IRAK4-L). The interaction of IRAK4-L with MyD88 facilitates the assembly of the myddosome complex, resulting in maximal activation of NF- $\kappa B$ and MAPK activation (Smith et al., 2019). Smith et al. showed that IRAK4-L is essential for leukemic cell function and that inhibition of this isoform suppressed leukemic cell growth (Smith et al., 2019). Pharmacological inhibition of IRAK4 with the IRAK4 Kinase Inhibitor CA-4948 reduced MDS cell engraftment in xenografts from $U 2 A F 1$ mutant MDS patients and in secondary recipients (Smith et al., 2019).

Interestingly, it has been reported that a large proportion of MDS/AML samples with SF3B1 mutation also show increased expression of the IRAK4 isoform encoding the fulllength protein (IRAK4-L), albeit via retention of a different exon (i.e. retention of the complete sequence of exon 6) (Choudhary et al., 2019). The expression of mutant SF3B1 in leukemia cells was associated with increased NF- $\kappa B$ activity, and treatment with CA-4948 led to decreased leukemic burden in mice xenografted with SF3B1 mutant MDS and AML cells. The SF3B1 mutation-induced IRAK4 activation led to TRAF6-mediated K63 ubiquitination of critical cell cycle and regulatory proteins involved in oncogenesis (Choudhary et al., 2019). The demonstration that SF3B1 mutations, similarly to $U 2 A F 1$ mutations, lead to increased expression of IRAK4-L indicates that IRAK/TRAF6 activation is a common downstream pathway in splicing factor mutant MDS and AML.

Taken together, these studies show that $S F 3 B 1$ mutations and $U 2 A F 1$ mutations induce the expression of an active IRAK4 isoform that may represent a therapeutic target, and that these mutations provide a link between splicing factor mutations and activation of chronic innate immune signaling in MDS and AML (Choudhary et al., 2019; Smith et al., 2019). NF- $\mathrm{BB}$ signaling has been shown to play a key role in the determination of quiescence versus the 
active state of HSCs (Nakagawa and Rathinam, 2018). Constitutive activation of NF- $\kappa \mathrm{B}$ signaling in mice leads to dysregulation of transcription factors that are critical to HSC selfrenewal and functions, resulting in HSC hyper-proliferation associated with loss of quiescence (Nakagawa et al., 2018). It is possible that hyper-activation of NF- $\kappa B$ signaling may increase the fitness of malignant hematopoietic stem and progenitor cells (HSPCs) in MDS and AML.

Overall, these studies provide evidence that different mutated splicing factors can converge on the same downstream signaling node to hyperactivate innate immune signaling, either by altering the pre-mRNA splicing of distinct target genes or by altering the premRNA splicing of the same target gene, albeit at different points of its transcript.

\section{SF3B1 mutations and elevated R-loops}

It has been known for many years that some components of the spliceosome, including SRSF1 and SRSF2, play a role in the maintenance of genomic stability (Li and Manley, 2005; Li et al., 2007; Xiao et al., 2007; Tresini et al., 2015; Chabot and Shkreta, 2016; Crossley et al., 2019).

Nguyen et al. showed that expression of the U2AF1 S34F mutation in human cancer cell lines leads to increased formation of R-loops (three-stranded structures comprising the nascent RNA hydridized with the template DNA and the displaced non-template DNA) (Nguyen et al., 2017). In a subsequent study, the same group demonstrated that U2AF1 S34F expression in cell lines activates ATR, a major player in the DNA damage response, in an Rloop dependent manner (Nguyen et al., 2018). Treatment of U2AF1 S34F expressing cell lines with ATR inhibitors promoted DNA damage and cell death, and the addition of spliceosome inhibitors could enhance these effects (Nguyen et al., 2018). The expression of U2AF1 S34F induced R-loops also in $\mathrm{CD}^{+} 4^{+}$cells isolated from human cord blood, making these cells susceptible to ATR inhibitors (Nguyen et al., 2018).

Chen et al. demonstrated that SRSF2 and U2AF1 mutations lead to accumulation of Rloops in human cell lines, resulting in increased DNA damage, replication stress and ATRChk1 pathway activation (Chen et al., 2018). Augmented R-loops were also observed in early blood progenitor cells isolated from the bone marrow of Srsf2-P95H knock-in mice, and the growth defect of hematopoietic progenitors could be partially corrected by overexpressing 
RNase H (an enzyme that can resolve R-loops), providing evidence that elevated R-loops may contribute directly to the MDS phenotype (Chen et al., 2018).

In a recent study, Singh et al. showed for the first time that increased R-loops and DNA damage also foccur in association with mutation of SF3B1 in a myeloid leukemia cell line, in MDS-patient derived iPSCs and in MDS patient bone marrow $\mathrm{CD}_{3} 4^{+}$cells (Singh et al., 2020). Activation of the ATR pathway was observed in SF3B1 mutant hematopoietic cells. SF3B1 mutant K562 cells and primary MDS patient bone marrow cells showed preferential sensitivity to the ATR inhibitor VE-821 and to UCN-01, an inhibitor of Chk1 (a critical substrate of ATR), indicating that ATR-Chk1 activation is important for the survival of SF3B1 mutant cells. Interestingly, the effects of these ATR or Chk1 inhibitors on SF3B1 mutant K562 cells and primary MDS patient bone marrow cells were enhanced by the splicing modulator Sudemycin D6, indicative of synergy between these drugs (Singh et al., 2020).

The finding that splicing factor mutation-associated R-loops lead to elevated levels of replication stress and ATR pathway activation has been recently corroborated in a study of primary $\mathrm{CD}^{+} 4^{+}$cells isolated from MDS patients with $S F 3 B 1$ or SRSF2 mutations (Flach et al., 2020). In accordance with the myeloid nature of MDS, R-loop accumulation was observed in CD34+, CD34+CD38- and CD33+ myeloid cells, but not in CD19+ B cells. In line with previous studies, splicing factor mutant MDS CD34+ cells were shown to be more susceptible to pharmacological inhibition of ATR resulting in elevated levels of DNA damage, cell cycle blockade, and cell death (Flach et al., 2020). Treatment with the splicing modulator pladienolide $\mathrm{B}$ in combination with the ATR inhibitor AZD6738 increased the sensitivity of splicing factor mutant MDS CD34+ cells mutated cells towards AZD6738, but did not result in significant additive or synergistic effects (Flach et al., 2020).

Taken together, these studies demonstrate that different mutated splicing factors have convergent effects on R-loop elevation leading to DNA damage in hematopoietic cells. It is currently not know why splicing factor mutant cells have a clonal advantage in human bone marrow, and it is possible that R-loop induced DNA damage may be a contributing factor.

\section{SF3B1 mutant MDS: therapeutic approaches}


A number of observations related to splicing factor mutations provided the rationale for targeting the spliceosome in myeloid malignancy patients: the mutual exclusivity of these mutations (Yoshida et al., 2011; Papaemmanuil et al., 2013), the fact that these mutations are not tolerated in a homozygous state (Lee et al., 2018), and the demonstration that the presence of the wild-type allele is required for the survival of splicing factor mutant cells (Zhou et al., 2015; Fei et al., 2016; Lee et al., 2016; Taylor et al., 2020).

The basis for the potential therapeutic use of spliceosome inhibitors in splicing factor mutant myeloid malignancies is that whilst wild-type cells can withstand a certain degree of spliceosome inhibition because they would still synthesize sufficient canonically spliced products, splicing factor mutant cells would be intolerant to further perturbation to the splicing process (Yoshimi and Abdel-Wahab, 2017).

Pre-clinical studies in vitro and in vivo in the mouse have demonstrated the potential of two spliceosome inhibitors, E7107 and H3B-8800, for the treatment of myeloid malignancies with splicing factor mutations (Lee et al., 2016; Obeng et al., 2016; Seiler et al., 2018).

In the most recent of these studies, Seiler et al. showed that H3B-8800 potently binds to SF3b complexes and inhibits splicing catalysis (Seiler et al., 2018). SF3B1 mutant K562 cells were preferentially sensitive to H3B-8800 compared to isogenic $S F 3 B 1$ wildtype cells. Moreover, treatment with H3B-8800 inhibited tumor growth in mice xenografted with SF3B1 mutant K562 cells, and reduced the leukemic burden in mice xenografted with SF3B1 mutant AML patient cells or with SRSF2 mutant CMML patient CD34+ cells (Seiler et al., 2018).

In previous studies, some concerns over the safety of E7107 treatment have been raised when two phase I clinical trials of this compound in patients with advanced/metastatic solid tumors were suspended after three patients developed vision issues (Eskens et al., 2013; Hong et al., 2014).

A phase 1 clinical trial (NCT02841540) of H3B-8800 explored its safety, pharmacokinetics and pharmacodynamics in 84 patients with MDS, AML and CMML, most of whom had SF3B1, SRSF2 or U2AF1 mutations. Although dose-dependent target engagement was observed and H3B-8800 was deemed to be safe, no complete or partial responses were achieved, with just over $10 \%$ of patients showing decreased red cell or platelet transfusion requirements (Steensma et al., 2019). The evaluation of H3B-8800 in combination with other treatments for MDS may be an option to explore. 
An important consideration is the emerging evidence that response to splicing modulators may vary depending on the splicing factor mutant allele present (Taylor et al., 2020). It was recently shown that the most frequent $S F 3 B 1$ and $S R S F 2$ mutations impact pre-mRNA splicing and RNA-binding affinity more prominently than the less common mutations of these genes, indicating that cells with SF3B1 K700E or SRSF2 P95H/L/R mutations may be more sensitive to treatment with splicing modulators (Taylor et al., 2020). These data suggest that stratification of myeloid malignancy patients based on their specific splicing factor mutations might need to be considered in clinical trials involving spliceosome-targeting drugs (Pellagatti and Boultwood, 2020a; Taylor et al., 2020).

Data from several studies showing that splicing factor mutation-associated R-loops lead to ATR pathway activation and susceptibility to pharmacological inhibition of ATR (Chen et al., 2018; Nguyen et al., 2018; Flach et al., 2020; Singh et al., 2020) provide a preclinical rationale for targeting ATR signaling in myeloid malignancy patients with these mutations. Notably, a phase 1 clinical trial to assess the safety, tolerability and efficacy of the ATR inhibitor ceralasertib (formerly known as AZD6738) in patients with MDS and CMML progressing on standard therapy is currently underway in the US (NCT03770429).

Hyperactivation of NF- $\mathrm{KB}$ signaling, resulting from aberrant splicing of IRAK4 leading to increased expression of the IRAK4-L isoform, has been shown to occur in SF3BI and U2AF1 mutant MDS and AML (Choudhary et al., 2019; Smith et al., 2019). The IRAK4 kinase inhibitor CA-4948 decreased the leukemic burden in mice xenografted with splicing factor mutant MDS and AML cells. CA-4948 has been evaluated in a clinical trial in patients with relapsed or refractory non-Hodgkin lymphoma, and it demonstrated preliminary clinical activity (Younes et al., 2019). A phase 1 clinical trial of CA-4948 is currently in progress in patients with high-risk MDS or AML (NCT04278768).

The drug luspatercept has been recently shown to be particularly effective in patients with SF3B1 mutant MDS-RS (Fenaux et al., 2020; Malcovati et al., 2020).

The transforming growth factor beta (TGF- $\beta$ ) pathway is involved in the regulation of many cellular processes, including cell growth and differentiation (Dong and Blobe, 2006). TGF- $\beta$ signaling is increased by means of activation of its downstream mediators SMAD2/3 in the bone marrow cells of MDS patients and in disease models of ineffective erythropoiesis 
(Zhou et al., 2008; Suragani et al., 2014b; Bataller et al., 2019). SMAD2/3 activation inhibits erythroid differentiation. Luspatercept, a recombinant fusion protein that binds TGF- $\beta$ superfamily ligands, resulted in reduced SMAD2/3 signaling and enhanced late-stage erythropoiesis in mouse models of MDS and $\beta$-thalassemia (Suragani et al., 2014a; Suragani et al., 2014b; Fenaux et al., 2019).

In a phase 2 clinical trial, luspatercept was shown to be effective for the treatment of anemia in patients with lower-risk MDS (Platzbecker et al., 2017). In a subsequent phase 3 trial, treatment with luspatercept significantly reduced the transfusion burden in almost $40 \%$ of patients with MDS-RS (Fenaux et al., 2020). More than $90 \%$ of these patients harbored a SF3B1 mutation, indicating that luspatercept can be particularly effective in this patient group (Fenaux et al., 2020; Malcovati et al., 2020). The biological basis of the drug's efficacy in MDS cases with $S F 3 B 1$ mutation remains to be elucidated. Luspatercept has been recently approved by both the U.S. Food and Drug Administration (FDA) and the European Medicines Agency for the treatment of transfusion-dependent anemia in patients with lowerrisk MDS-RS. Luspatercept is the first FDA approved drug in MDS in over a decade.

\section{Conclusions and future perspectives}

Our understanding of the impact of $S F 3 B 1$ and of other splicing factor mutations on the pathophysiology of MDS is increasing rapidly. Many aberrantly spliced target genes of the most commonly mutated splicing factors have been identified, but it is important to determine which of these are key contributors to the MDS phenotype. Some functional studies have shown that certain target genes play an important role in disease pathophysiology, but further investigations are required to establish whether other genes may also be pivotal. The convergence of different mutated splicing factors on common dysregulated downstream pathways and cellular processes, such as increased R-loops and hyperactivation of NF- $\mathrm{B}$ signaling, is clearly an important factor.

Another key question is how splicing factor mutations and other co-occurring gene mutations co-operate to impact the MDS phenotype and to drive disease progression. A few studies have started addressing this aspect using in vitro and in vivo models, but further investigations are required given the heterogeneity of co-mutation patterns in MDS.

The effects of splicing factor mutations on pre-mRNA splicing and gene expression have been investigated mainly in MDS bone marrow HSPCs or mononuclear cells. However, the 
investigation of specific lineages affected in MDS, such as erythroid and myeloid progenitors, is still a relatively underexplored area of research. It will also be important to determine the impact of splicing factor mutations on the MDS transcriptome at single-cell resolution.

A number of drugs have been or are being evaluated in clinical trials of patients with myeloid malignancies, including splicing factor mutant MDS. It is encouraging to see that our knowledge of the effects of splicing factor mutations and their target genes is being actively translated into new potential therapeutic approaches to target splicing factor mutant MDS cells.

\section{Acknowledgements}

We are grateful to Blood Cancer UK (grants 13042 and 19004) and Leukaemia UK (grant PG17/002) for support.

\section{Conflicts of interest}

None. 


\section{References}

Allikmets, R., Raskind, W.H., Hutchinson, A., Schueck, N.D., Dean, M., Koeller, D.M., 1999. Mutation of a putative mitochondrial iron transporter gene (ABC7) in X-linked sideroblastic anemia and ataxia (XLSA/A). Hum Mol Genet. 8, 743-749.

Armstrong, R.N., Steeples, V., Singh, S., Sanchi, A., Boultwood, J., Pellagatti, A., 2018. Splicing factor mutations in the myelodysplastic syndromes: target genes and therapeutic approaches. Adv Biol Regul. 67, 13-29.

Bataller, A., Montalban-Bravo, G., Soltysiak, K.A., Garcia-Manero, G., 2019. The role of TGFbeta in hematopoiesis and myeloid disorders. Leukemia. 33, 1076-1089.

Bejar, R., Stevenson, K., Abdel-Wahab, O., Galili, N., Nilsson, B., Garcia-Manero, G., Kantarjian, H., Raza, A., Levine, R.L., Neuberg, D., Ebert, B.L., 2011. Clinical effect of point mutations in myelodysplastic syndromes. N Engl J Med. 364, 2496-2506.

Bejar, R., Stevenson, K.E., Caughey, B.A., Abdel-Wahab, O., Steensma, D.P., Galili, N., Raza, A., Kantarjian, H., Levine, R.L., Neuberg, D., Garcia-Manero, G., Ebert, B.L., 2012. Validation of a prognostic model and the impact of mutations in patients with lower-risk myelodysplastic syndromes. J Clin Oncol. 30, 3376-3382.

Bekri, S., Kispal, G., Lange, H., Fitzsimons, E., Tolmie, J., Lill, R., Bishop, D.F., 2000. Human ABC7 transporter: gene structure and mutation causing X-linked sideroblastic anemia with ataxia with disruption of cytosolic iron-sulfur protein maturation. Blood. 96, 3256-3264.

Bernard, E., Nannya, Y., Hasserjian, R.P., Devlin, S.M., Tuechler, H., Medina-Martinez, J.S., Yoshizato, T., Shiozawa, Y., Saiki, R., Malcovati, L., Levine, M.F., Arango, J.E., Zhou, Y., Sole, F., Cargo, C.A., Haase, D., Creignou, M., Germing, U., Zhang, Y., Gundem, G., Sarian, A., van de Loosdrecht, A.A., Jadersten, M., Tobiasson, M., Kosmider, O., Follo, M.Y., Thol, F., Pinheiro, R.F., Santini, V., Kotsianidis, I., Boultwood, J., Santos, F.P.S., Schanz, J., Kasahara, S., Ishikawa, T., Tsurumi, H., Takaori-Kondo, A., Kiguchi, T., Polprasert, C., Bennett, J.M., Klimek, V.M., Savona, M.R., Belickova, M., Ganster, C., Palomo, L., Sanz, G., Ades, L., Della Porta, M.G., Smith, A.G., Werner, Y., Patel, M., Viale, A., Vanness, K., Neuberg, D.S., Stevenson, K.E., Menghrajani, K., Bolton, K.L., Fenaux, P., Pellagatti, A., Platzbecker, U., Heuser, M., Valent, P., Chiba, S., Miyazaki, Y., Finelli, C., Voso, M.T., Shih, L.Y., Fontenay, M., Jansen, J.H., Cervera, J., Atsuta, Y., Gattermann, N., Ebert, B.L., Bejar, R., Greenberg, P.L., Cazzola, M., Hellstrom-Lindberg, E., Ogawa, S., Papaemmanuil, E., 2020. Implications of TP53 allelic state for genome stability, clinical presentation and outcomes in myelodysplastic syndromes. Nat Med. 26, 1549-1556.

Bondu, S., Alary, A.S., Lefevre, C., Houy, A., Jung, G., Lefebvre, T., Rombaut, D., Boussaid, I., Bousta, A., Guillonneau, F., Perrier, P., Alsafadi, S., Wassef, M., Margueron, R., Rousseau, A., Droin, N., Cagnard, N., Kaltenbach, S., Winter, S., Kubasch, A.S., Bouscary, D., Santini, V., Toma, A., Hunault, M., Stamatoullas, A., Gyan, E., Cluzeau, T., Platzbecker, U., Ades, L., Puy, H., Stern, M.H., Karim, Z., Mayeux, P., Nemeth, E., Park, S., Ganz, T., Kautz, L., Kosmider, O., Fontenay, M., 2019. A variant erythroferrone disrupts iron homeostasis in SF3B1-mutated myelodysplastic syndrome. Sci Transl Med. 11.

Boultwood, J., Pellagatti, A., Nikpour, M., Pushkaran, B., Fidler, C., Cattan, H., Littlewood, T.J., Malcovati, L., Della Porta, M.G., Jadersten, M., Killick, S., Giagounidis, A., Bowen, D., Hellstrom-Lindberg, E., Cazzola, M., Wainscoat, J.S., 2008. The role of the iron transporter ABCB7 in refractory anemia with ring sideroblasts. PLoS One. 3, e1970.

Chabot, B., Shkreta, L., 2016. Defective control of pre-messenger RNA splicing in human disease. J Cell Biol. 212, 13-27. 
Chamseddine, A.N., Jabbour, E., Kantarjian, H.M., Bohannan, Z.S., Garcia-Manero, G., 2016. Unraveling Myelodysplastic Syndromes: Current Knowledge and Future Directions. Curr Oncol Rep. 18, 4.

Chang, C.J., Kotini, A.G., Olszewska, M., Georgomanoli, M., Teruya-Feldstein, J., Sperber, H., Sanchez, R., DeVita, R., Martins, T.J., Abdel-Wahab, O., Bradley, R.K., Papapetrou, E.P., 2018. Dissecting the Contributions of Cooperating Gene Mutations to Cancer Phenotypes and Drug Responses with Patient-Derived iPSCs. Stem Cell Reports. 10, 1610-1624.

Chaudhary, P.M., Eby, M.T., Jasmin, A., Kumar, A., Liu, L., Hood, L., 2000. Activation of the NF-kappaB pathway by caspase 8 and its homologs. Oncogene. 19, 4451-4460.

Chen, L., Chen, J.Y., Huang, Y.J., Gu, Y., Qiu, J., Qian, H., Shao, C., Zhang, X., Hu, J., Li, H., He, S., Zhou, Y., Abdel-Wahab, O., Zhang, D.E., Fu, X.D., 2018. The Augmented RLoop Is a Unifying Mechanism for Myelodysplastic Syndromes Induced by High-Risk Splicing Factor Mutations. Mol Cell. 69, 412-425.

Choudhary, G.S., Smith, M.A., Pellagatti, A., Bhagat, T.D., Gordon, S., Pandey, S., Shah, N., Aluri, S., Booher, R.N., Ramachandra, M., Samson, M.E., Pradhan, K., Bowman, T.V., Pillai, M.M., Guha, C., Wickrema, A., Will, B., Shastri, A., Steidl, U.G., Boultwood, J., Starczynowski, D.T., Verma, A., 2019. SF3B1 Mutations Induce Oncogenic IRAK4 Isoforms and Activate Targetable Innate Immune Pathways in MDS and AML. Blood (ASH Annual Meeting Abstracts). 134, 4224.

Clough, C., Pangallo, J., Sarchi, M., Busch, S., Abkowitz, J.L., Bradley, R.K., Doulatov, S., 2020. Coordinated Mis-Splicing of Multiple Mitochondrial Iron Metabolism Genes Causes Ring Sideroblast Formation in SF3B1-Mutant MDS. Blood (ASH Annual Meeting Abstracts). 136, 4.

Colla, S., Ong, D.S., Ogoti, Y., Marchesini, M., Mistry, N.A., Clise-Dwyer, K., Ang, S.A., Storti, P., Viale, A., Giuliani, N., Ruisaard, K., Ganan Gomez, I., Bristow, C.A., Estecio, M., Weksberg, D.C., Ho, Y.W., Hu, B., Genovese, G., Pettazzoni, P., Multani, A.S., Jiang, S., Hua, S., Ryan, M.C., Carugo, A., Nezi, L., Wei, Y., Yang, H., D'Anca, M., Zhang, L., Gaddis, S., Gong, T., Horner, J.W., Heffernan, T.P., Jones, P., Cooper, L.J., Liang, H., Kantarjian, H., Wang, Y.A., Chin, L., Bueso-Ramos, C., Garcia-Manero, G., DePinho, R.A., 2015. Telomere dysfunction drives aberrant hematopoietic differentiation and myelodysplastic syndrome. Cancer Cell. 27, 644-657.

Crossley, M.P., Bocek, M., Cimprich, K.A., 2019. R-Loops as Cellular Regulators and Genomic Threats. Mol Cell. 73, 398-411.

Dalton, W.B., Helmenstine, E., Pieterse, L., Li, B., Gocke, C.D., Donaldson, J., Xiao, Z., Gondek, L.P., Ghiaur, G., Gojo, I., Smith, B.D., Levis, M.J., DeZern, A.E., 2020. The K666N mutation in SF3B1 is associated with increased progression of MDS and distinct RNA splicing. Blood Adv. 4, 1192-1196.

Damm, F., Kosmider, O., Gelsi-Boyer, V., Renneville, A., Carbuccia, N., Hidalgo-Curtis, C., Della Valle, V., Couronné, L., Scourzic, L., Chesnais, V., Guerci-Bresler, A., Slama, B., Beyne-Rauzy, O., Schmidt-Tanguy, A., Stamatoullas-Bastard, A., Dreyfus, F., Prébet, T., de Botton, S., Vey, N., Morgan, M.A., Cross, N.C., Preudhomme, C., Birnbaum, D., Bernard, O.A., Fontenay, M., Myélodysplasies, G.F.d., 2012. Mutations affecting mRNA splicing define distinct clinical phenotypes and correlate with patient outcome in myelodysplastic syndromes. Blood. 119, 3211-3218.

de Witte, T., Bowen, D., Robin, M., Malcovati, L., Niederwieser, D., Yakoub-Agha, I., Mufti, G.J., Fenaux, P., Sanz, G., Martino, R., Alessandrino, E.P., Onida, F., Symeonidis, A., Passweg, J., Kobbe, G., Ganser, A., Platzbecker, U., Finke, J., van Gelder, M., van de Loosdrecht, A.A., Ljungman, P., Stauder, R., Volin, L., Deeg, H.J., Cutler, C., Saber, W., Champlin, R., Giralt, S., Anasetti, C., Kröger, N., 2017. Allogeneic 
hematopoietic stem cell transplantation for MDS and CMML: recommendations from an international expert panel. Blood. 129, 1753-1762.

Dolatshad, H., Pellagatti, A., Fernandez-Mercado, M., Yip, B.H., Malcovati, L., Attwood, M., Przychodzen, B., Sahgal, N., Kanapin, A.A., Lockstone, H., Scifo, L., Vandenberghe, P., Papaemmanuil, E., Smith, C.W., Campbell, P.J., Ogawa, S., Maciejewski, J.P., Cazzola, M., Savage, K.I., Boultwood, J., 2015. Disruption of SF3B1 results in deregulated expression and splicing of key genes and pathways in myelodysplastic syndrome hematopoietic stem and progenitor cells. Leukemia. 29, 10921103.

Dolatshad, H., Pellagatti, A., Liberante, F.G., Llorian, M., Repapi, E., Steeples, V., Roy, S., Scifo, L., Armstrong, R.N., Shaw, J., Yip, B.H., Killick, S., Kusec, R., Taylor, S., Mills, K.I., Savage, K.I., Smith, C.W., Boultwood, J., 2016. Cryptic splicing events in the iron transporter $\mathrm{ABCB} 7$ and other key target genes in SF3B1-mutant myelodysplastic syndromes. Leukemia. 30, 2322-2331.

Dong, M., Blobe, G.C., 2006. Role of transforming growth factor-beta in hematologic malignancies. Blood. 107, 4589-4596.

Eskens, F.A., Ramos, F.J., Burger, H., O'Brien, J.P., Piera, A., de Jonge, M.J., Mizui, Y., Wiemer, E.A., Carreras, M.J., Baselga, J., Tabernero, J., 2013. Phase I pharmacokinetic and pharmacodynamic study of the first-in-class spliceosome inhibitor E7107 in patients with advanced solid tumors. Clin Cancer Res. 19, 6296-6304.

Fei, D.L., Motowski, H., Chatrikhi, R., Prasad, S., Yu, J., Gao, S., Kielkopf, C.L., Bradley, R.K., Varmus, H., 2016. Wild-Type U2AF1 Antagonizes the Splicing Program Characteristic of U2AF1-Mutant Tumors and Is Required for Cell Survival. PLoS Genet. 12 , e1006384.

Fei, D.L., Zhen, T., Durham, B., Ferrarone, J., Zhang, T., Garrett, L., Yoshimi, A., AbdelWahab, O., Bradley, R.K., Liu, P., Varmus, H., 2018. Impaired hematopoiesis and leukemia development in mice with a conditional knock-in allele of a mutant splicing factor gene U2af1. Proc Natl Acad Sci U S A. 115, E10437-E10446.

Fenaux, P., Kiladjian, J.J., Platzbecker, U., 2019. Luspatercept for the treatment of anemia in myelodysplastic syndromes and primary myelofibrosis. Blood. 133, 790-794.

Fenaux, P., Platzbecker, U., Mufti, G.J., Garcia-Manero, G., Buckstein, R., Santini, V., DiezCampelo, M., Finelli, C., Cazzola, M., Ilhan, O., Sekeres, M.A., Falantes, J.F., Arrizabalaga, B., Salvi, F., Giai, V., Vyas, P., Bowen, D., Selleslag, D., DeZern, A.E., Jurcic, J.G., Germing, U., Gotze, K.S., Quesnel, B., Beyne-Rauzy, O., Cluzeau, T., Voso, M.T., Mazure, D., Vellenga, E., Greenberg, P.L., Hellstrom-Lindberg, E., Zeidan, A.M., Ades, L., Verma, A., Savona, M.R., Laadem, A., Benzohra, A., Zhang, J., Rampersad, A., Dunshee, D.R., Linde, P.G., Sherman, M.L., Komrokji, R.S., List, A.F., 2020. Luspatercept in Patients with Lower-Risk Myelodysplastic Syndromes. N Engl J Med. $382,140-151$.

Flach, J., Jann, J.C., Knaflic, A., Riabov, V., Streuer, A., Altrock, E., Xu, Q., Schmitt, N., Oblander, J., Nowak, V., Danner, J., Mehralivand, A., Hofmann, F., Palme, I., Jawhar, A., Wuchter, P., Metzgeroth, G., Nolte, F., Hofmann, W.K., Nowak, D., 2020. Replication stress signaling is a therapeutic target in myelodysplastic syndromes with splicing factor mutations. Haematologica. Online ahead of print.

Graubert, T.A., Shen, D., Ding, L., Okeyo-Owuor, T., Lunn, C.L., Shao, J., Krysiak, K., Harris, C.C., Koboldt, D.C., Larson, D.E., McLellan, M.D., Dooling, D.J., Abbott, R.M., Fulton, R.S., Schmidt, H., Kalicki-Veizer, J., O'Laughlin, M., Grillot, M., Baty, J., Heath, S., Frater, J.L., Nasim, T., Link, D.C., Tomasson, M.H., Westervelt, P., DiPersio, J.F., Mardis, E.R., Ley, T.J., Wilson, R.K., Walter, M.J., 2011. Recurrent mutations in the U2AF1 splicing factor in myelodysplastic syndromes. Nat Genet. 44, 53-57. 
Greenberg, P.L., Tuechler, H., Schanz, J., Sanz, G., Garcia-Manero, G., Sole, F., Bennett, J.M., Bowen, D., Fenaux, P., Dreyfus, F., Kantarjian, H., Kuendgen, A., Levis, A., Malcovati, L., Cazzola, M., Cermak, J., Fonatsch, C., Le Beau, M.M., Slovak, M.L., Krieger, O., Luebbert, M., Maciejewski, J., Magalhaes, S.M., Miyazaki, Y., Pfeilstocker, M., Sekeres, M., Sperr, W.R., Stauder, R., Tauro, S., Valent, P., Vallespi, T., van de Loosdrecht, A.A., Germing, U., Haase, D., 2012. Revised international prognostic scoring system for myelodysplastic syndromes. Blood. 120, 2454-2465.

Haase, D., Stevenson, K.E., Neuberg, D., Maciejewski, J.P., Nazha, A., Sekeres, M.A., Ebert, B.L., Garcia-Manero, G., Haferlach, C., Haferlach, T., Kern, W., Ogawa, S., Nagata, Y., Yoshida, K., Graubert, T.A., Walter, M.J., List, A.F., Komrokji, R.S., Padron, E., Sallman, D., Papaemmanuil, E., Campbell, P.J., Savona, M.R., Seegmiller, A., Ades, L., Fenaux, P., Shih, L.Y., Bowen, D., Groves, M.J., Tauro, S., Fontenay, M., Kosmider, O., Bar-Natan, M., Steensma, D., Stone, R., Heuser, M., Thol, F., Cazzola, M., Malcovati, L., Karsan, A., Ganster, C., Hellstrom-Lindberg, E., Boultwood, J., Pellagatti, A., Santini, V., Quek, L., Vyas, P., Tuchler, H., Greenberg, P.L., Bejar, R., International Working Group for MDS Molecular Prognostic Committee, 2019. TP53 mutation status divides myelodysplastic syndromes with complex karyotypes into distinct prognostic subgroups. Leukemia. 33, 1747-1758.

Haferlach, T., Nagata, Y., Grossmann, V., Okuno, Y., Bacher, U., Nagae, G., Schnittger, S., Sanada, M., Kon, A., Alpermann, T., Yoshida, K., Roller, A., Nadarajah, N., Shiraishi, Y., Shiozawa, Y., Chiba, K., Tanaka, H., Koeffler, H.P., Klein, H.U., Dugas, M., Aburatani, H., Kohlmann, A., Miyano, S., Haferlach, C., Kern, W., Ogawa, S., 2014. Landscape of genetic lesions in 944 patients with myelodysplastic syndromes. Leukemia. 28, 241-247.

Hershberger, C.E., Moyer, D.C., Adema, V., Kerr, C.M., Walter, W., Hutter, S., Meggendorfer, M., Baer, C., Kern, W., Nadarajah, N., Twardziok, S., Sekeres, M.A., Haferlach, C., Haferlach, T., Maciejewski, J.P., Padgett, R.A., 2020. Complex landscape of alternative splicing in myeloid neoplasms. Leukemia. Online ahead of print.

Hong, D.S., Kurzrock, R., Naing, A., Wheler, J.J., Falchook, G.S., Schiffman, J.S., Faulkner, N., Pilat, M.J., O'Brien, J., LoRusso, P., 2014. A phase I, open-label, single-arm, doseescalation study of E7107, a precursor messenger ribonucleic acid (pre-mRNA) splicesome inhibitor administered intravenously on days 1 and 8 every 21 days to patients with solid tumors. Invest New Drugs. 32, 436-444.

Hsu, J., Reilly, A., Hayes, B.J., Clough, C.A., Konnick, E.Q., Torok-Storb, B., Gulsuner, S., Wu, D., Becker, P.S., Keel, S.B., Abkowitz, J.L., Doulatov, S., 2019. Reprogramming identifies functionally distinct stages of clonal evolution in myelodysplastic syndromes. Blood. 134, 186-198.

Hu, W.H., Johnson, H., Shu, H.B., 2000. Activation of NF-kappaB by FADD, Casper, and caspase-8. J Biol Chem. 275, 10838-10844.

Inoue, D., Bradley, R.K., Abdel-Wahab, O., 2016. Spliceosomal gene mutations in myelodysplasia: molecular links to clonal abnormalities of hematopoiesis. Genes Dev. 30, 989-1001.

Inoue, D., Chew, G.L., Liu, B., Michel, B.C., Pangallo, J., D'Avino, A.R., Hitchman, T., North, K., Lee, S.C., Bitner, L., Block, A., Moore, A.R., Yoshimi, A., Escobar-Hoyos, L., Cho, H., Penson, A., Lu, S.X., Taylor, J., Chen, Y., Kadoch, C., Abdel-Wahab, O., Bradley, R.K., 2019. Spliceosomal disruption of the non-canonical BAF complex in cancer. Nature. 574, 432-436.

Jacob, A.G., Smith, C.W.J., 2017. Intron retention as a component of regulated gene expression programs. Hum Genet. 136, 1043-1057. 
Joshi, P., Halene, S., Abdel-Wahab, O., 2017. How do messenger RNA splicing alterations drive myelodysplasia? Blood. 129, 2465-2470.

Kim, E., Ilagan, J.O., Liang, Y., Daubner, G.M., Lee, S.C., Ramakrishnan, A., Li, Y., Chung, Y.R., Micol, J.B., Murphy, M.E., Cho, H., Kim, M.K., Zebari, A.S., Aumann, S., Park, C.Y., Buonamici, S., Smith, P.G., Deeg, H.J., Lobry, C., Aifantis, I., Modis, Y., Allain, F.H., Halene, S., Bradley, R.K., Abdel-Wahab, O., 2015. SRSF2 Mutations Contribute to Myelodysplasia by Mutant-Specific Effects on Exon Recognition. Cancer Cell. 27, 617630.

Kon, A., Yamazaki, S., Nannya, Y., Kataoka, K., Ota, Y., Nakagawa, M.M., Yoshida, K., Shiozawa, Y., Morita, M., Yoshizato, T., Sanada, M., Nakayama, M., Koseki, H., Nakauchi, H., Ogawa, S., 2018. Physiological Srsf2 P95H expression causes impaired hematopoietic stem cell functions and aberrant RNA splicing in mice. Blood. 131, 621635.

Lee, S.C., Dvinge, H., Kim, E., Cho, H., Micol, J.B., Chung, Y.R., Durham, B.H., Yoshimi, A., Kim, Y.J., Thomas, M., Lobry, C., Chen, C.W., Pastore, A., Taylor, J., Wang, X., Krivtsov, A., Armstrong, S.A., Palacino, J., Buonamici, S., Smith, P.G., Bradley, R.K., Abdel-Wahab, O., 2016. Modulation of splicing catalysis for therapeutic targeting of leukemia with mutations in genes encoding spliceosomal proteins. Nat Med. 22, 672678.

Lee, S.C., North, K., Kim, E., Jang, E., Obeng, E., Lu, S.X., Liu, B., Inoue, D., Yoshimi, A., Ki, M., Yeo, M., Zhang, X.J., Kim, M.K., Cho, H., Chung, Y.R., Taylor, J., Durham, B.H., Kim, Y.J., Pastore, A., Monette, S., Palacino, J., Seiler, M., Buonamici, S., Smith, P.G., Ebert, B.L., Bradley, R.K., Abdel-Wahab, O., 2018. Synthetic Lethal and Convergent Biological Effects of Cancer-Associated Spliceosomal Gene Mutations. Cancer Cell. 34, 225-241.

Li, X., Manley, J.L., 2005. Inactivation of the SR protein splicing factor ASF/SF2 results in genomic instability. Cell. 122, 365-378.

Li, X., Niu, T., Manley, J.L., 2007. The RNA binding protein RNPS1 alleviates ASF/SF2 depletion-induced genomic instability. RNA. 13, 2108-2115.

Liu, B., Liu, Z., Chen, S., Ki, M., Erickson, C., Reis-Filho, J.S., Durham, B.H., Chang, Q., de Stanchina, E., Sun, Y., Rabadan, R., Abdel-Wahab, O., Chandarlapaty, S., 2020. Mutant SF3B1 promotes AKT and NF-kB driven mammary tumorigenesis. J Clin Invest. Online ahead of print.

Madan, V., Kanojia, D., Li, J., Okamoto, R., Sato-Otsubo, A., Kohlmann, A., Sanada, M., Grossmann, V., Sundaresan, J., Shiraishi, Y., Miyano, S., Thol, F., Ganser, A., Yang, H., Haferlach, T., Ogawa, S., Koeffler, H.P., 2015. Aberrant splicing of U12-type introns is the hallmark of ZRSR2 mutant myelodysplastic syndrome. Nat Commun. 6, 6042.

Makishima, H., Visconte, V., Sakaguchi, H., Jankowska, A.M., Abu Kar, S., Jerez, A., Przychodzen, B., Bupathi, M., Guinta, K., Afable, M.G., Sekeres, M.A., Padgett, R.A., Tiu, R.V., Maciejewski, J.P., 2012. Mutations in the spliceosome machinery, a novel and ubiquitous pathway in leukemogenesis. Blood. 119, 3203-3210.

Makishima, H., Yoshizato, T., Yoshida, K., Sekeres, M.A., Radivoyevitch, T., Suzuki, H., Przychodzen, B., Nagata, Y., Meggendorfer, M., Sanada, M., Okuno, Y., Hirsch, C., Kuzmanovic, T., Sato, Y., Sato-Otsubo, A., LaFramboise, T., Hosono, N., Shiraishi, Y., Chiba, K., Haferlach, C., Kern, W., Tanaka, H., Shiozawa, Y., Gomez-Segui, I., Husseinzadeh, H.D., Thota, S., Guinta, K.M., Dienes, B., Nakamaki, T., Miyawaki, S., Saunthararajah, Y., Chiba, S., Miyano, S., Shih, L.Y., Haferlach, T., Ogawa, S., Maciejewski, J.P., 2017. Dynamics of clonal evolution in myelodysplastic syndromes. Nat Genet. 49, 204-212. 
Malcovati, L., Karimi, M., Papaemmanuil, E., Ambaglio, I., Jädersten, M., Jansson, M., Elena, C., Gallì, A., Walldin, G., Della Porta, M.G., Raaschou-Jensen, K., Travaglino, E., Kallenbach, K., Pietra, D., Ljungström, V., Conte, S., Boveri, E., Invernizzi, R., Rosenquist, R., Campbell, P.J., Cazzola, M., Hellström Lindberg, E., 2015. SF3B1 mutation identifies a distinct subset of myelodysplastic syndrome with ring sideroblasts. Blood. 126, 233-241.

Malcovati, L., Papaemmanuil, E., Bowen, D.T., Boultwood, J., Della Porta, M.G., Pascutto, C., Travaglino, E., Groves, M.J., Godfrey, A.L., Ambaglio, I., Gallì, A., Da Vià, M.C., Conte, S., Tauro, S., Keenan, N., Hyslop, A., Hinton, J., Mudie, L.J., Wainscoat, J.S., Futreal, P.A., Stratton, M.R., Campbell, P.J., Hellström-Lindberg, E., Cazzola, M., Chronic Myeloid Disorders Working Group of the International Cancer Genome Consortium and of the Associazione Italiana per la Ricerca sul Cancro Gruppo Italiano Malattie Mieloproliferative, 2011. Clinical significance of SF3B1 mutations in myelodysplastic syndromes and myelodysplastic/myeloproliferative neoplasms. Blood. 118, 6239-6246.

Malcovati, L., Stevenson, K., Papaemmanuil, E., Neuberg, D., Bejar, R., Boultwood, J., Bowen, D.T., Campbell, P.J., Ebert, B.L., Fenaux, P., Haferlach, T., Heuser, M., Jansen, J.H., Komrokji, R.S., Maciejewski, J.P., Walter, M.J., Fontenay, M., Garcia-Manero, G., Graubert, T.A., Karsan, A., Meggendorfer, M., Pellagatti, A., Sallman, D.A., Savona, M.R., Sekeres, M.A., Steensma, D.P., Tauro, S., Thol, F., Vyas, P., Van de Loosdrecht, A.A., Haase, D., Tuchler, H., Greenberg, P.L., Ogawa, S., Hellstrom-Lindberg, E., Cazzola, M., 2020. SF3B1-mutant MDS as a distinct disease subtype: a proposal from the International Working Group for the Prognosis of MDS. Blood. 136, 157-170.

Matera, A.G., Wang, Z., 2014. A day in the life of the spliceosome. Nat Rev Mol Cell Biol. $15,108-121$.

Meggendorfer, M., Roller, A., Haferlach, T., Eder, C., Dicker, F., Grossmann, V., Kohlmann, A., Alpermann, T., Yoshida, K., Ogawa, S., Koeffler, H.P., Kern, W., Haferlach, C., Schnittger, S., 2012. SRSF2 mutations in 275 cases with chronic myelomonocytic leukemia (CMML). Blood. 120, 3080-3088.

Mian, S.A., Rouault-Pierre, K., Smith, A.E., Seidl, T., Pizzitola, I., Kizilors, A., Kulasekararaj, A.G., Bonnet, D., Mufti, G.J., 2015. SF3B1 mutant MDS-initiating cells may arise from the haematopoietic stem cell compartment. Nat Commun. 6, 10004.

Mian, S.A., Smith, A.E., Kulasekararaj, A.G., Kizilors, A., Mohamedali, A.M., Lea, N.C., Mitsopoulos, K., Ford, K., Nasser, E., Seidl, T., Mufti, G.J., 2013. Spliceosome mutations exhibit specific associations with epigenetic modifiers and proto-oncogenes mutated in myelodysplastic syndrome. Haematologica. 98, 1058-1066.

Mupo, A., Seiler, M., Sathiaseelan, V., Pance, A., Yang, Y., Agrawal, A.A., Iorio, F., Bautista, R., Pacharne, S., Tzelepis, K., Manes, N., Wright, P., Papaemmanuil, E., Kent, D.G., Campbell, P.C., Buonamici, S., Bolli, N., Vassiliou, G.S., 2017. Hemopoieticspecific Sf3b1-K700E knock-in mice display the splicing defect seen in human MDS but develop anemia without ring sideroblasts. Leukemia. 31, 720-727.

Nagata, Y., Makishima, H., Kerr, C.M., Przychodzen, B.P., Aly, M., Goyal, A., Awada, H., Asad, M.F., Kuzmanovic, T., Suzuki, H., Yoshizato, T., Yoshida, K., Chiba, K., Tanaka, H., Shiraishi, Y., Miyano, S., Mukherjee, S., LaFramboise, T., Nazha, A., Sekeres, M.A., Radivoyevitch, T., Haferlach, T., Ogawa, S., Maciejewski, J.P., 2019. Invariant patterns of clonal succession determine specific clinical features of myelodysplastic syndromes. Nat Commun. 10, 5386.

Nakagawa, M.M., Chen, H., Rathinam, C.V., 2018. Constitutive Activation of NF-kappaB Pathway in Hematopoietic Stem Cells Causes Loss of Quiescence and Deregulated Transcription Factor Networks. Front Cell Dev Biol. 6, 143. 
Nakagawa, M.M., Rathinam, C.V., 2018. Constitutive Activation of the Canonical NFkappaB Pathway Leads to Bone Marrow Failure and Induction of Erythroid Signature in Hematopoietic Stem Cells. Cell Rep. 25, 2094-2109 e2094.

Nguyen, H.D., Leong, W.Y., Li, W., Reddy, P.N.G., Sullivan, J.D., Walter, M.J., Zou, L., Graubert, T.A., 2018. Spliceosome Mutations Induce R Loop-Associated Sensitivity to ATR Inhibition in Myelodysplastic Syndromes. Cancer Res. 78, 5363-5374.

Nguyen, H.D., Yadav, T., Giri, S., Saez, B., Graubert, T.A., Zou, L., 2017. Functions of Replication Protein A as a Sensor of R Loops and a Regulator of RNaseH1. Mol Cell. $65,832-847$ e834.

Nikpour, M., Scharenberg, C., Liu, A., Conte, S., Karimi, M., Mortera-Blanco, T., Giai, V., Fernandez-Mercado, M., Papaemmanuil, E., Högstrand, K., Jansson, M., Vedin, I., Wainscoat, J.S., Campbell, P., Cazzola, M., Boultwood, J., Grandien, A., HellströmLindberg, E., 2013. The transporter ABCB7 is a mediator of the phenotype of acquired refractory anemia with ring sideroblasts. Leukemia. 27, 889-896.

Nilsen, T.W., Graveley, B.R., 2010. Expansion of the eukaryotic proteome by alternative splicing. Nature. 463, 457-463.

Obeng, E.A., Chappell, R.J., Seiler, M., Chen, M.C., Campagna, D.R., Schmidt, P.J., Schneider, R.K., Lord, A.M., Wang, L., Gambe, R.G., McConkey, M.E., Ali, A.M., Raza, A., Yu, L., Buonamici, S., Smith, P.G., Mullally, A., Wu, C.J., Fleming, M.D., Ebert, B.L., 2016. Physiologic Expression of Sf3b1(K700E) Causes Impaired Erythropoiesis, Aberrant Splicing, and Sensitivity to Therapeutic Spliceosome Modulation. Cancer Cell. 30, 404-417.

Oeckinghaus, A., Ghosh, S., 2009. The NF-kappaB family of transcription factors and its regulation. Cold Spring Harb Perspect Biol. 1, a000034.

Ogawa, S., 2019. Genetics of MDS. Blood. 133, 1049-1059.

Papaemmanuil, E., Cazzola, M., Boultwood, J., Malcovati, L., Vyas, P., Bowen, D., Pellagatti, A., Wainscoat, J.S., Hellstrom-Lindberg, E., Gambacorti-Passerini, C., Godfrey, A.L., Rapado, I., Cvejic, A., Rance, R., McGee, C., Ellis, P., Mudie, L.J., Stephens, P.J., McLaren, S., Massie, C.E., Tarpey, P.S., Varela, I., Nik-Zainal, S., Davies, H.R., Shlien, A., Jones, D., Raine, K., Hinton, J., Butler, A.P., Teague, J.W., Baxter, E.J., Score, J., Galli, A., Della Porta, M.G., Travaglino, E., Groves, M., Tauro, S., Munshi, N.C., Anderson, K.C., El-Naggar, A., Fischer, A., Mustonen, V., Warren, A.J., Cross, N.C., Green, A.R., Futreal, P.A., Stratton, M.R., Campbell, P.J., Chronic Myeloid Disorders Working Group of the International Cancer Genome Consortium, 2011. Somatic SF3B1 mutation in myelodysplasia with ring sideroblasts. N Engl J Med. $365,1384-1395$.

Papaemmanuil, E., Gerstung, M., Malcovati, L., Tauro, S., Gundem, G., Van Loo, P., Yoon, C.J., Ellis, P., Wedge, D.C., Pellagatti, A., Shlien, A., Groves, M.J., Forbes, S.A., Raine, K., Hinton, J., Mudie, L.J., McLaren, S., Hardy, C., Latimer, C., Della Porta, M.G., O'Meara, S., Ambaglio, I., Galli, A., Butler, A.P., Walldin, G., Teague, J.W., Quek, L., Sternberg, A., Gambacorti-Passerini, C., Cross, N.C., Green, A.R., Boultwood, J., Vyas, P., Hellstrom-Lindberg, E., Bowen, D., Cazzola, M., Stratton, M.R., Campbell, P.J., Chronic Myeloid Disorders Working Group of the International Cancer Genome Consortium, 2013. Clinical and biological implications of driver mutations in myelodysplastic syndromes. Blood. 122, 3616-3627.

Patel, B.J., Przychodzen, B., Thota, S., Radivoyevitch, T., Visconte, V., Kuzmanovic, T., Clemente, M., Hirsch, C., Morawski, A., Souaid, R., Saygin, C., Nazha, A., Demarest, B., LaFramboise, T., Sakaguchi, H., Kojima, S., Carraway, H.E., Ogawa, S., Makishima, H., Sekeres, M.A., Maciejewski, J.P., 2017. Genomic determinants of chronic myelomonocytic leukemia. Leukemia. 31, 2815-2823. 
Patnaik, M.M., Lasho, T.L., Finke, C.M., Hanson, C.A., Hodnefield, J.M., Knudson, R.A., Ketterling, R.P., Pardanani, A., Tefferi, A., 2013. Spliceosome mutations involving SRSF2, SF3B1, and U2AF35 in chronic myelomonocytic leukemia: prevalence, clinical correlates, and prognostic relevance. Am J Hematol. 88, 201-206.

Pellagatti, A., Armstrong, R.N., Steeples, V., Sharma, E., Repapi, E., Singh, S., Sanchi, A., Radujkovic, A., Horn, P., Dolatshad, H., Roy, S., Broxholme, J., Lockstone, H., Taylor, S., Giagounidis, A., Vyas, P., Schuh, A., Hamblin, A., Papaemmanuil, E., Killick, S., Malcovati, L., Hennrich, M.L., Gavin, A.C., Ho, A.D., Luft, T., Hellstrom-Lindberg, E., Cazzola, M., Smith, C.W.J., Smith, S., Boultwood, J., 2018. Impact of spliceosome mutations on RNA splicing in myelodysplasia: dysregulated genes/pathways and clinical associations. Blood. 132, 1225-1240.

Pellagatti, A., Boultwood, J., 2015. The molecular pathogenesis of the myelodysplastic syndromes. Eur J Haematol. 95, 3-15.

Pellagatti, A., Boultwood, J., 2017. Splicing factor gene mutations in the myelodysplastic syndromes: impact on disease phenotype and therapeutic applications. Adv Biol Regul. $63,59-70$.

Pellagatti, A., Boultwood, J., 2020a. Spliceosome mutations: 1 plus 1 does not always equal 2. Blood. 136, 1471-1472.

Pellagatti, A., Boultwood, J., 2020b. Splicing factor mutant myelodysplastic syndromes: Recent advances. Adv Biol Regul. 75, 100655.

Pellagatti, A., Roy, S., Di Genua, C., Burns, A., McGraw, K., Valletta, S., Larrayoz, M.J., Fernandez-Mercado, M., Mason, J., Killick, S., Mecucci, C., Calasanz, M.J., List, A., Schuh, A., Boultwood, J., 2016. Targeted resequencing analysis of 31 genes commonly mutated in myeloid disorders in serial samples from myelodysplastic syndrome patients showing disease progression. Leukemia. 30, 247-250.

Platzbecker, U., Germing, U., Gotze, K.S., Kiewe, P., Mayer, K., Chromik, J., Radsak, M., Wolff, T., Zhang, X., Laadem, A., Sherman, M.L., Attie, K.M., Giagounidis, A., 2017. Luspatercept for the treatment of anaemia in patients with lower-risk myelodysplastic syndromes (PACE-MDS): a multicentre, open-label phase 2 dose-finding study with long-term extension study. Lancet Oncol. 18, 1338-1347.

Saez, B., Walter, M.J., Graubert, T.A., 2017. Splicing factor gene mutations in hematologic malignancies. Blood. 129, 1260-1269.

Seiler, M., Yoshimi, A., Darman, R., Chan, B., Keaney, G., Thomas, M., Agrawal, A.A., Caleb, B., Csibi, A., Sean, E., Fekkes, P., Karr, C., Klimek, V., Lai, G., Lee, L., Kumar, P., Lee, S.C., Liu, X., Mackenzie, C., Meeske, C., Mizui, Y., Padron, E., Park, E., Pazolli, E., Peng, S., Prajapati, S., Taylor, J., Teng, T., Wang, J., Warmuth, M., Yao, H., Yu, L., Zhu, P., Abdel-Wahab, O., Smith, P.G., Buonamici, S., 2018. H3B-8800, an orally available small-molecule splicing modulator, induces lethality in spliceosomemutant cancers. Nat Med. 24, 497-504.

Shikama, Y., Yamada, M., Miyashita, T., 2003. Caspase-8 and caspase-10 activate NFkappaB through RIP, NIK and IKKalpha kinases. Eur J Immunol. 33, 1998-2006.

Shiozawa, Y., Malcovati, L., Galli, A., Sato-Otsubo, A., Kataoka, K., Sato, Y., Watatani, Y., Suzuki, H., Yoshizato, T., Yoshida, K., Sanada, M., Makishima, H., Shiraishi, Y., Chiba, K., Hellstrom-Lindberg, E., Miyano, S., Ogawa, S., Cazzola, M., 2018. Aberrant splicing and defective mRNA production induced by somatic spliceosome mutations in myelodysplasia. Nat Commun. 9, 3649.

Shirai, C.L., Ley, J.N., White, B.S., Kim, S., Tibbitts, J., Shao, J., Ndonwi, M., Wadugu, B., Duncavage, E.J., Okeyo-Owuor, T., Liu, T., Griffith, M., McGrath, S., Magrini, V., Fulton, R.S., Fronick, C., O'Laughlin, M., Graubert, T.A., Walter, M.J., 2015. Mutant 
U2AF1 Expression Alters Hematopoiesis and Pre-mRNA Splicing In Vivo. Cancer Cell. 27, 631-643.

Shirai, C.L., White, B.S., Tripathi, M., Tapia, R., Ley, J.N., Ndonwi, M., Kim, S., Shao, J., Carver, A., Saez, B., Fulton, R.S., Fronick, C., O'Laughlin, M., Lagisetti, C., Webb, T.R., Graubert, T.A., Walter, M.J., 2017. Mutant U2AF1-expressing cells are sensitive to pharmacological modulation of the spliceosome. Nat Commun. 8, 14060.

Singh, S., Ahmed, D., Dolatshad, H., Tatwavedi, D., Schulze, U., Sanchi, A., Ryley, S., Dhir, A., Carpenter, L., Watt, S.M., Roberts, D.J., Abdel-Aal, A.M., Sayed, S.K., Mohamed, S.A., Schuh, A., Vyas, P., Killick, S., Kotini, A.G., Papapetrou, E.P., Wiseman, D.H., Pellagatti, A., Boultwood, J., 2020. SF3B1 mutations induce R-loop accumulation and DNA damage in MDS and leukemia cells with therapeutic implications. Leukemia. 34, 2525-2530.

Smith, M.A., Choudhary, G.S., Pellagatti, A., Choi, K., Bolanos, L.C., Bhagat, T.D., GordonMitchell, S., Von Ahrens, D., Pradhan, K., Steeples, V., Kim, S., Steidl, U., Walter, M., Fraser, I.D.C., Kulkarni, A., Salomonis, N., Komurov, K., Boultwood, J., Verma, A., Starczynowski, D.T., 2019. U2AF1 mutations induce oncogenic IRAK4 isoforms and activate innate immune pathways in myeloid malignancies. Nat Cell Biol. 21, 640-650.

Steensma, D.P., 2015. Myelodysplastic Syndromes: Diagnosis and Treatment. Mayo Clin Proc. 90, 969-983.

Steensma, D.P., Bejar, R., Jaiswal, S., Lindsley, R.C., Sekeres, M.A., Hasserjian, R.P., Ebert, B.L., 2015. Clonal hematopoiesis of indeterminate potential and its distinction from myelodysplastic syndromes. Blood. 126, 9-16.

Steensma, D.P., Wermke, M., Klimek, V.M., Greenberg, P.L., Font, P., Komrokji, R.S., Yang, J., Brunner, A.M., Carraway, H.E., Ades, L., Al-Kali, A., Alonso Dominguez, J.M., Alonso, A., Coombs, C.C., Deeg, J.H., Donnellan, W.B., Foran, J.M., GarciaManero, G., Maris, M.B., McMasters, M., Micol, J.-B., Perez De Oteyza, J., Thol, F., Wang, E.S., Watts, J.M., Buonamici, S., Kim, A., Gourineni, V., Marino, A.J., Rioux, N., Schindler, J., Smith, S., Yao, H., Yuan, X., Yu, K., Platzbecker, U., 2019. Results of a Clinical Trial of H3B-8800, a Splicing Modulator, in Patients with Myelodysplastic Syndromes (MDS), Acute Myeloid Leukemia (AML) or Chronic Myelomonocytic Leukemia (CMML). Blood (ASH Annual Meeting Abstracts). 134, 673.

Suragani, R.N., Cadena, S.M., Cawley, S.M., Sako, D., Mitchell, D., Li, R., Davies, M.V., Alexander, M.J., Devine, M., Loveday, K.S., Underwood, K.W., Grinberg, A.V., Quisel, J.D., Chopra, R., Pearsall, R.S., Seehra, J., Kumar, R., 2014a. Transforming growth factor-beta superfamily ligand trap ACE-536 corrects anemia by promoting late-stage erythropoiesis. Nat Med. 20, 408-414.

Suragani, R.N., Cawley, S.M., Li, R., Wallner, S., Alexander, M.J., Mulivor, A.W., Gardenghi, S., Rivella, S., Grinberg, A.V., Pearsall, R.S., Kumar, R., 2014b. Modified activin receptor IIB ligand trap mitigates ineffective erythropoiesis and disease complications in murine beta-thalassemia. Blood. 123, 3864-3872.

Taylor, J., Mi, X., North, K., Binder, M., Penson, A., Lasho, T., Knorr, K., Haddadin, M., Liu, B., Pangallo, J., Benbarche, S., Wiseman, D., Tefferi, A., Halene, S., Liang, Y., Patnaik, M.M., Bradley, R.K., Abdel-Wahab, O., 2020. Single-cell genomics reveals the genetic and molecular bases for escape from mutational epistasis in myeloid neoplasms. Blood. 136, 1477-1486.

Thol, F., Kade, S., Schlarmann, C., Loffeld, P., Morgan, M., Krauter, J., Wlodarski, M.W., Kolking, B., Wichmann, M., Gorlich, K., Gohring, G., Bug, G., Ottmann, O., Niemeyer, C.M., Hofmann, W.K., Schlegelberger, B., Ganser, A., Heuser, M., 2012. Frequency and prognostic impact of mutations in SRSF2, U2AF1, and ZRSR2 in patients with myelodysplastic syndromes. Blood. 119, 3578-3584. 
Tresini, M., Warmerdam, D.O., Kolovos, P., Snijder, L., Vrouwe, M.G., Demmers, J.A., van, I.W.F., Grosveld, F.G., Medema, R.H., Hoeijmakers, J.H., Mullenders, L.H., Vermeulen, W., Marteijn, J.A., 2015. The core spliceosome as target and effector of non-canonical ATM signalling. Nature. 523, 53-58.

Wahl, M.C., Will, C.L., Luhrmann, R., 2009. The spliceosome: design principles of a dynamic RNP machine. Cell. 136, 701-718.

Walter, M.J., Shen, D., Shao, J., Ding, L., White, B.S., Kandoth, C., Miller, C.A., Niu, B., McLellan, M.D., Dees, N.D., Fulton, R., Elliot, K., Heath, S., Grillot, M., Westervelt, P., Link, D.C., DiPersio, J.F., Mardis, E., Ley, T.J., Wilson, R.K., Graubert, T.A., 2013. Clonal diversity of recurrently mutated genes in myelodysplastic syndromes. Leukemia. $27,1275-1282$.

Wang, X., Song, X., Yan, X., 2019. Effect of RNA splicing machinery gene mutations on prognosis of patients with MDS: A meta-analysis. Medicine (Baltimore). 98, e15743.

Wu, L., Song, L., Xu, L., Chang, C., Xu, F., Wu, D., He, Q., Su, J., Zhou, L., Xiao, C., Zhang, Z., Zhao, Y., Chen, S., Li, X., 2016. Genetic landscape of recurrent ASXL1, U2AF1, SF3B1, SRSF2, and EZH2 mutations in 304 Chinese patients with myelodysplastic syndromes. Tumour Biol. 37, 4633-4640.

Wu, S.J., Kuo, Y.Y., Hou, H.A., Li, L.Y., Tseng, M.H., Huang, C.F., Lee, F.Y., Liu, M.C., Liu, C.W., Lin, C.T., Chen, C.Y., Chou, W.C., Yao, M., Huang, S.Y., Ko, B.S., Tang, J.L., Tsay, W., Tien, H.F., 2012. The clinical implication of SRSF2 mutation in patients with myelodysplastic syndrome and its stability during disease evolution. Blood. 120, 3106-3111.

Wu, S.J., Tang, J.L., Lin, C.T., Kuo, Y.Y., Li, L.Y., Tseng, M.H., Huang, C.F., Lai, Y.J., Lee, F.Y., Liu, M.C., Liu, C.W., Hou, H.A., Chen, C.Y., Chou, W.C., Yao, M., Huang, S.Y., Ko, B.S., Tsay, W., Tien, H.F., 2013. Clinical implications of U2AF1 mutation in patients with myelodysplastic syndrome and its stability during disease progression. Am J Hematol. 88, E277-282.

Wu, Y., Albrecht, T.R., Baillat, D., Wagner, E.J., Tong, L., 2017. Molecular basis for the interaction between Integrator subunits IntS9 and IntS11 and its functional importance. Proc Natl Acad Sci U S A. 114, 4394-4399.

Xiao, R., Sun, Y., Ding, J.H., Lin, S., Rose, D.W., Rosenfeld, M.G., Fu, X.D., Li, X., 2007. Splicing regulator SC35 is essential for genomic stability and cell proliferation during mammalian organogenesis. Mol Cell Biol. 27, 5393-5402.

Yip, B.H., Dolatshad, H., Roy, S., Pellagatti, A., Boultwood, J., 2016. Impact of Splicing Factor Mutations on Pre-mRNA Splicing in the Myelodysplastic Syndromes. Curr Pharm Des. 22, 2333-2344.

Yip, B.H., Steeples, V., Repapi, E., Armstrong, R.N., Llorian, M., Roy, S., Shaw, J., Dolatshad, H., Taylor, S., Verma, A., Bartenstein, M., Vyas, P., Cross, N.C., Malcovati, L., Cazzola, M., Hellstrom-Lindberg, E., Ogawa, S., Smith, C.W., Pellagatti, A., Boultwood, J., 2017. The U2AF1S34F mutation induces lineage-specific splicing alterations in myelodysplastic syndromes. J Clin Invest. 127, 2206-2221.

Yoshida, K., Sanada, M., Shiraishi, Y., Nowak, D., Nagata, Y., Yamamoto, R., Sato, Y., Sato-Otsubo, A., Kon, A., Nagasaki, M., Chalkidis, G., Suzuki, Y., Shiosaka, M., Kawahata, R., Yamaguchi, T., Otsu, M., Obara, N., Sakata-Yanagimoto, M., Ishiyama, K., Mori, H., Nolte, F., Hofmann, W.K., Miyawaki, S., Sugano, S., Haferlach, C., Koeffler, H.P., Shih, L.Y., Haferlach, T., Chiba, S., Nakauchi, H., Miyano, S., Ogawa, S., 2011. Frequent pathway mutations of splicing machinery in myelodysplasia. Nature. 478, 64-69.

Yoshimi, A., Abdel-Wahab, O., 2017. Splicing factor mutations in MDS RARS and MDS/MPN-RS-T. Int J Hematol. 105, 720-731. 
Yoshimi, A., Lin, K.T., Wiseman, D.H., Rahman, M.A., Pastore, A., Wang, B., Lee, S.C., Micol, J.B., Zhang, X.J., de Botton, S., Penard-Lacronique, V., Stein, E.M., Cho, H., Miles, R.E., Inoue, D., Albrecht, T.R., Somervaille, T.C.P., Batta, K., Amaral, F., Simeoni, F., Wilks, D.P., Cargo, C., Intlekofer, A.M., Levine, R.L., Dvinge, H., Bradley, R.K., Wagner, E.J., Krainer, A.R., Abdel-Wahab, O., 2019. Coordinated alterations in RNA splicing and epigenetic regulation drive leukaemogenesis. Nature. 574, 273-277.

Younes, A., Nowakowski, G., Rosenthal, A.C., Leslie, L.A., Tun, H.W., Lunning, M.A., Isufi, I., Martell, R., Patel, K., 2019. Phase 1 Dose-Finding Study Investigating CA4948, an IRAK4 Kinase Inhibitor, in Patients with R/R NHL: Report of Initial Efficacy and Updated Safety Information. Blood (ASH Annual Meeting Abstracts). 134, 5327.

Zhou, L., Nguyen, A.N., Sohal, D., Ying Ma, J., Pahanish, P., Gundabolu, K., Hayman, J., Chubak, A., Mo, Y., Bhagat, T.D., Das, B., Kapoun, A.M., Navas, T.A., Parmar, S., Kambhampati, S., Pellagatti, A., Braunchweig, I., Zhang, Y., Wickrema, A., Medicherla, S., Boultwood, J., Platanias, L.C., Higgins, L.S., List, A.F., Bitzer, M., Verma, A., 2008. Inhibition of the TGF-beta receptor I kinase promotes hematopoiesis in MDS. Blood. 112, 3434-3443.

Zhou, Q., Derti, A., Ruddy, D., Rakiec, D., Kao, I., Lira, M., Gibaja, V., Chan, H., Yang, Y., Min, J., Schlabach, M.R., Stegmeier, F., 2015. A chemical genetics approach for the functional assessment of novel cancer genes. Cancer Res. 75, 1949-1958. 
Figure 1. In patients with myeloid malignancies, selection occurs against co-occurrence of two frequent splicing factor mutations, such as $S F 3 B 1^{\mathrm{K} 700 \mathrm{E}}$ and $S R S F 2^{\mathrm{P} 95 \mathrm{H}}$, in the same cell. Co-occurrence of less common splicing factor mutations, such as $S F 3 B 1^{\mathrm{H} 662 \mathrm{Q}}$ or $S F 3 B 1^{\mathrm{K} 666 \mathrm{~N}}$ or rare amino acid changes at SRSF2 P95, has been observed. Two U2AF1 mutations can cooccur in the same cell, when the mutations are in cis and one wild-type U2AF1 allele is preserved. 